\title{
The results of operation in 46 cases of malformation of the anus and rectum
}

\author{
VALENTINE A. J. SWAIN AND S. M. TUCKER \\ From the Queen Elizabeth Hospital for Children, Hackney Road, London
}

EDITORIAL SYNOPSIS This paper presents an analysis of 46 cases of ano-rectal malformations and reviews the results of treatment. Good control was achieved in over two-thirds of the cases.

During the last decade, largely due to the work of Rhoads, Pipes, and Randall (1948), Potts, Riker, and DeBoer (1954), Browne (1955), and Stephens (1953a and b), interest has been directed to reconstruction operations in cases of malformation of the rectum above the pelvic floor. Till then permanent colostomies had been instituted for these conditions in the first few days of life.

A small personal series of $\mathbf{4 6}$ patients, consisting of 20 high and 26 low cases (Table I), is presented as it was thought timely to see what had happened to these infants, but, as the subdivision of the cases into separate types reduces the number in each group, one can only get an impression. Furthermore, some of the infants are still so young that no conclusions can be reached.

\section{TABLE I}

ANALYSIS OF ANO-RECTAL DEFORMITIES

\begin{tabular}{|c|c|c|}
\hline & Low Type & High Type \\
\hline $\begin{array}{l}\text { No. of cases } \\
\text { Sex distribution }\end{array}$ & $\begin{array}{l}26 \\
816(61 \cdot 5 \%) \\
\$ 10\end{array}$ & $\begin{array}{l}20 \\
\text { o16 } \\
+4\end{array}$ \\
\hline $\begin{array}{l}\text { Associated anomalies } \\
\text { Deaths }\end{array}$ & $\begin{array}{l}23 \% \\
1(3.8 \%)\end{array}$ & $\begin{array}{l}75 \% \text { to } 50 \% \text { severe } \\
5(25 \%)\end{array}$ \\
\hline $\begin{array}{l}\text { Results } \\
\text { Good } \\
\text { Fair } \\
\text { Poor } \\
\text { Others }\end{array}$ & $\begin{array}{l}12(46 \%) \\
6(23 \%) \\
8\end{array}$ & $\begin{array}{l}4(25 \%) \\
6(37 \%) \\
3(19 \%) \\
3\end{array}$ \\
\hline
\end{tabular}

There is considerable variation of opinion regarding the nomenclature of congenital ano-rectal deformities. Swenson (1958) groups all these abnormalities under the heading of 'imperforate anus'. This is perhaps not wholly suitable, although the word 'anus' may be used in its purely embryological sense as the termination of the bowel, or in its usual clinical sense as the termination of the bowel com- plete with sphincter mechanism. The majority of cases of so-called imperforate anus have some opening, even though it may be displaced and small. Only one case in our series could be labelled as true imperforate anus, so we have not continued with this term, except in this single instance. The classification of Ladd and Gross (1941) into four types has been abandoned because it did not seem to give a useful grouping of cases with similar origins, treatment, or prognosis but Stephens (1953a and b), of Melbourne, has divided all the ano-rectal anomalies into two major groups. We propose to follow this basic classification with certain modifications. The nomenclature is similar to that suggested by Gough (1961).

1 ANAL DEFORMITIES This group includes all the 'low' cases (Table II), all those cases where the bowel passes through the pelvic floor before going wrong, e.g., ectopic (vaginal, vestibular, and perineal) and

TABLE II

LOW ANO-RECTAL DEFORMITIES

\begin{tabular}{|c|c|}
\hline $\begin{array}{l}\text { No. of cases } \\
\text { Sex distribution }\end{array}$ & $\begin{array}{l}26 \\
\$ 16(\delta 61 \cdot 5 \%) \\
+10\end{array}$ \\
\hline $\begin{array}{l}\text { Types } \\
\text { Anal stenosis } \\
\text { Covered anus } \\
\text { Ectopic anus }\left\{\begin{array}{l}\text { Vaginal } \\
\text { Vestibular } \\
\text { Perineal }\end{array}\right. \\
\text { Imperforate anus }\end{array}$ & $\begin{array}{r}12 \\
7 \\
2 \\
2 \\
2 \\
1\end{array}$ \\
\hline $\begin{array}{l}\text { Associated anomalies } \\
\text { Mongolism } \\
\text { Congenital heart } \\
\text { Vertebral } \\
\text { Hypospadias }\end{array}$ & $\left.\begin{array}{l}3 \\
2 \\
1 \\
1\end{array}\right\} 23 \%$ \\
\hline Deaths & $1(3.8 \%)$ \\
\hline $\begin{array}{l}\text { Results } \\
\text { Good } \\
\text { Fair } \\
\text { Untraced or too early }\end{array}$ & $\begin{array}{l}12(46 \%) \\
6(23 \%) \\
8\end{array}$ \\
\hline
\end{tabular}


covered anus (with or without microscopic opening), imperforate anus, and ano-rectal stenosis (Fig. 1).

2 IMPERFORATE RECTAL DEFORMITIES In this group the bowel stops on or above the pelvic floor and is often complicated by communications of the distal bowel with various portions of the genito-urinary tract and perineum. This group we have termed the 'high' types (Table III) and they include ano-rectal agenesis with fistula, ano-rectal agenesis, rectal atresia, and cloaca (Fig. 2).

\section{ASSOCIATED ANOMALIES}

Table IV shows that these associated anomalies are three times more frequent in the high malformations ( $75 \%$ ) compared with the low variety ( $23 \%)$. Those infants suffering from severe cardiac defects died in the first few days of life.
TABLE III

HIGH ANO-RECTAL DEFORMITIES

\begin{tabular}{|c|c|}
\hline $\begin{array}{l}\text { No. of cases } \\
\text { Sex distribution }\end{array}$ & $\begin{array}{l}20 \\
\text { o } 16(80 \%) \\
\uparrow 4\end{array}$ \\
\hline $\begin{array}{l}\text { Types } \\
\text { Anorectal agenesis } \\
\text { Anorectal agenesis, with fistula } \\
\text { Rectal atresia }\end{array}$ & $\begin{array}{r}7 \\
12 \\
1\end{array}$ \\
\hline $\begin{array}{l}\text { Associated anomalies } \\
\text { Renal } \\
\text { Vertebral } \\
\text { Congenital heart disease } \\
\text { Alimentary } \\
\text { Mongolism } \\
\text { Genitalia }\end{array}$ & $\begin{array}{l}6 \\
4 \\
5 \\
2 \\
1 \\
3\end{array} \mid \begin{array}{l}75 \% \text { to } 50 \% \\
\end{array}$ \\
\hline Deaths & $4(20 \%)$ \\
\hline $\begin{array}{l}\text { Results } \\
\text { Good } \\
\text { Fair } \\
\text { Poor } \\
\text { Too young to assess }\end{array}$ & $\begin{array}{l}4(25 \%) \\
6(37 \%) \\
3(19 \%) \\
3(19 \%)\end{array}$ \\
\hline
\end{tabular}
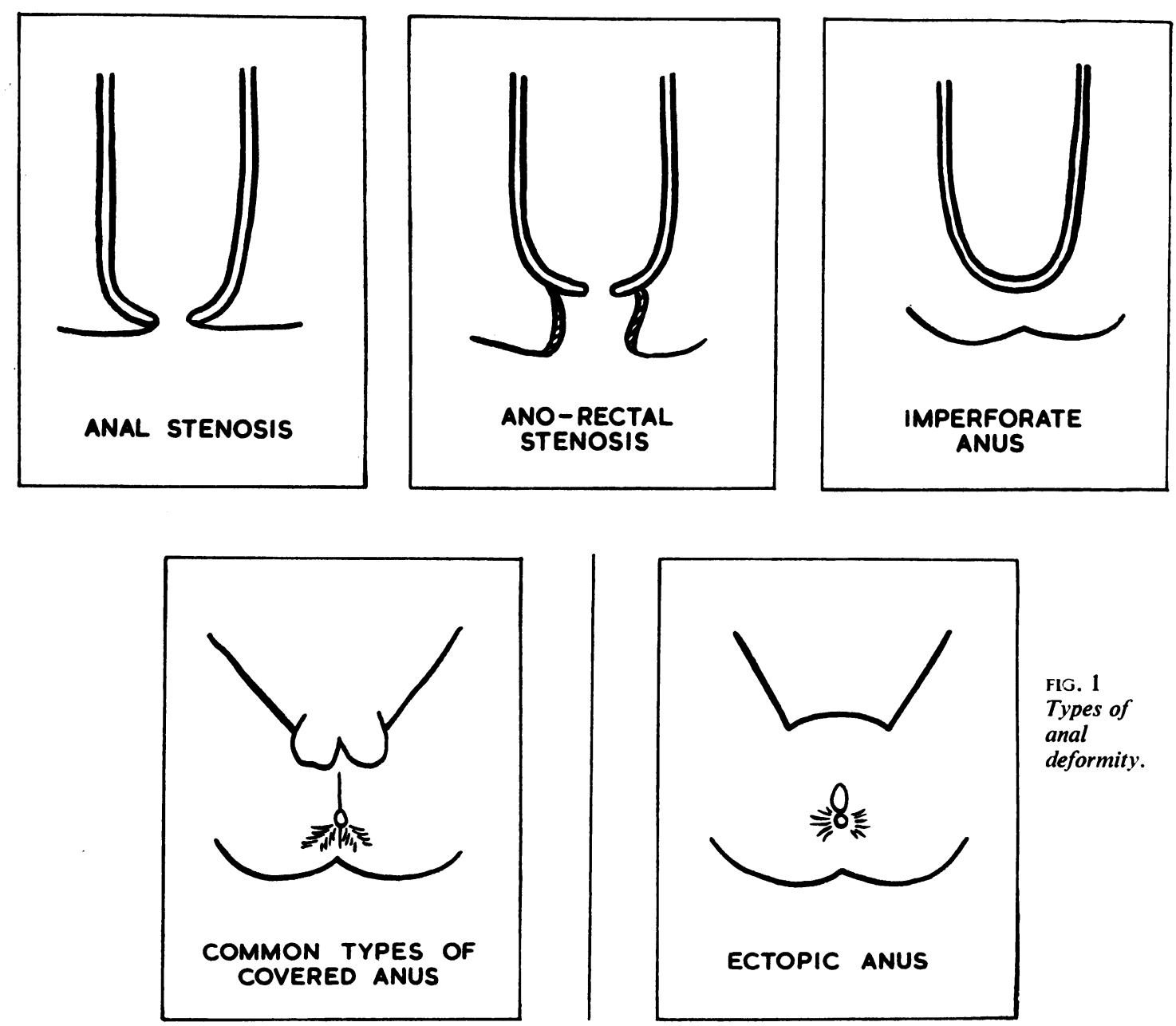

FIG. 1

Types of anal deformity. 

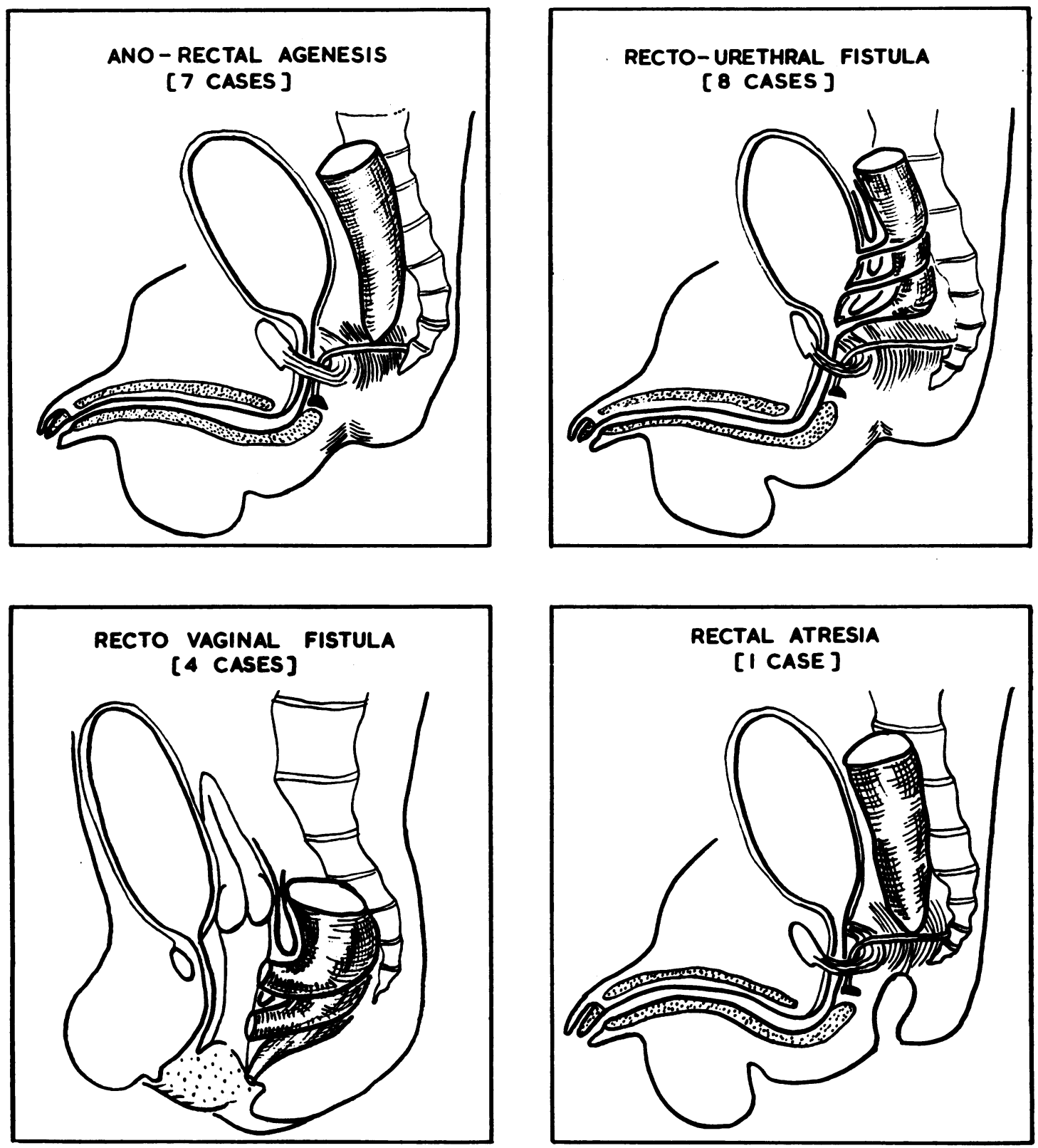

FIG. 2. Types of imperforate rectal deformity (after Stephens, 1953).

URINARY DISORDERS By far the most common of these in the high group are abnormalities of the ureters and kidney; this is not surprising as the development of the urinary tract is closely bound up with that of the bowel. The low cases (anal group abnormalities) occur after the processes of subdivision are concluded and are therefore less liable to serious urinary or spinal implication.
Urinary-rectal communications are shown by the presence of meconium in the urethra or in the urine (Fig. 3) but some may be overlooked for the fistulous opening may be small and become blocked early by mucosal debris. Urinary infection, apart from that occurring with fistulas, more often arises from an associated hydroureter and/or hydronephrosis (Fig. 4). The presence of pus cells in the urine will call 
TABLE IV

ASSOCIATED CONGENITAL ANOMALIES

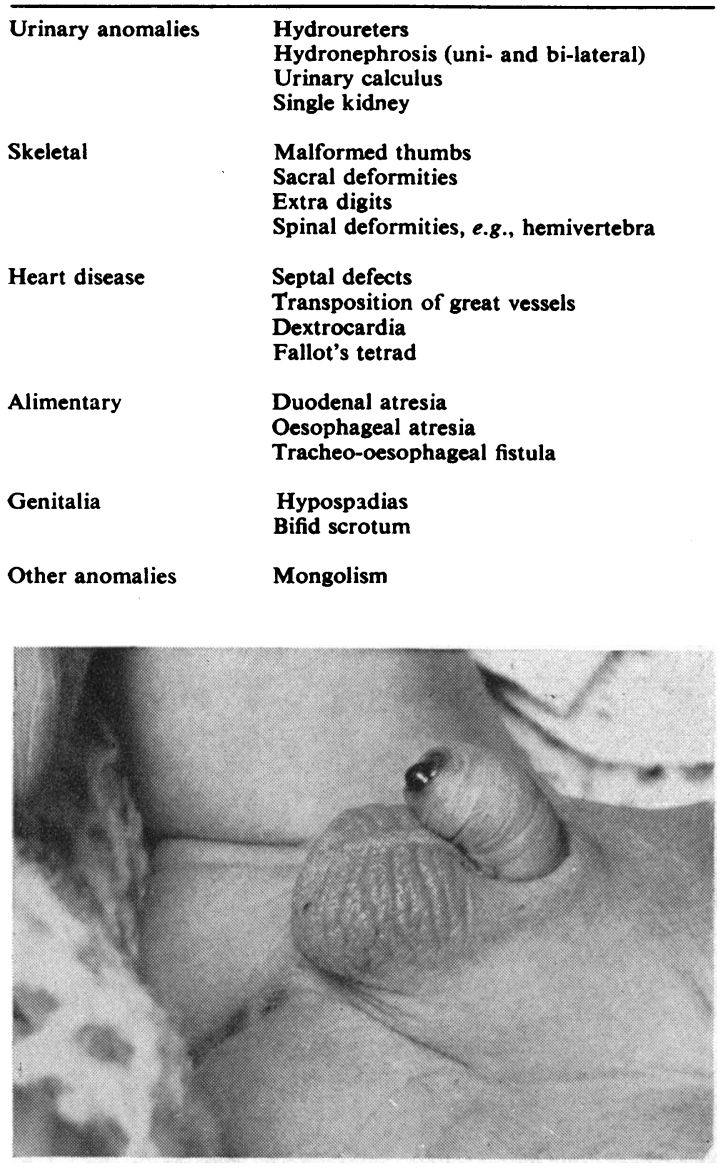

FIG. 3. Recto-urethral fistula with the passage of meconium per urethram.

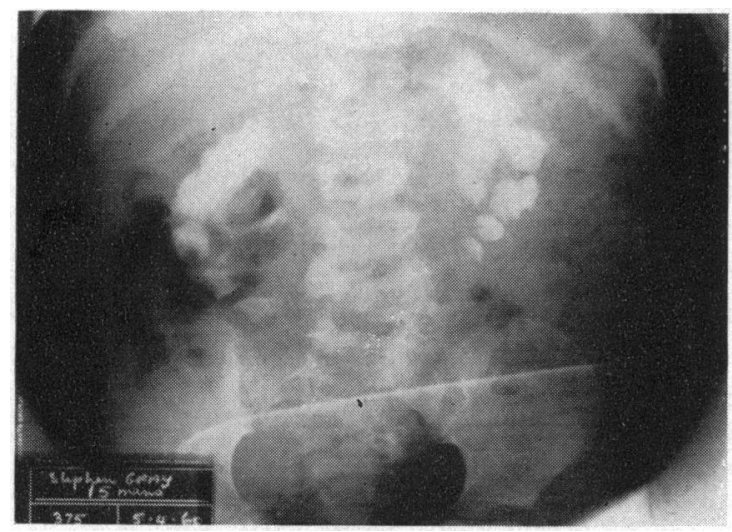

FIG. 4. Bilateral hydronephrosis and lumbo-sacral deformity associated with recto-urethral fistula. for pyelography. Sometimes dilated ureters are seen at operation not having been suspected previously. It is wise to carry out routine pyelography as Potts suggests. In one case renal stones were formed, probably as the result of delayed closure of a rectourethral fistula.

VERTEBRAL ANOMALIES These, especially sacrococcygeal deficiencies, imply poor development of the muscles of the pelvic diaphragm and probably associated neurogenic disorders of the bladder. Bony deformity in the thoraco-lumbar region may be associated with malposition of the kidneys or renal hypoplasia (Fig. 5).

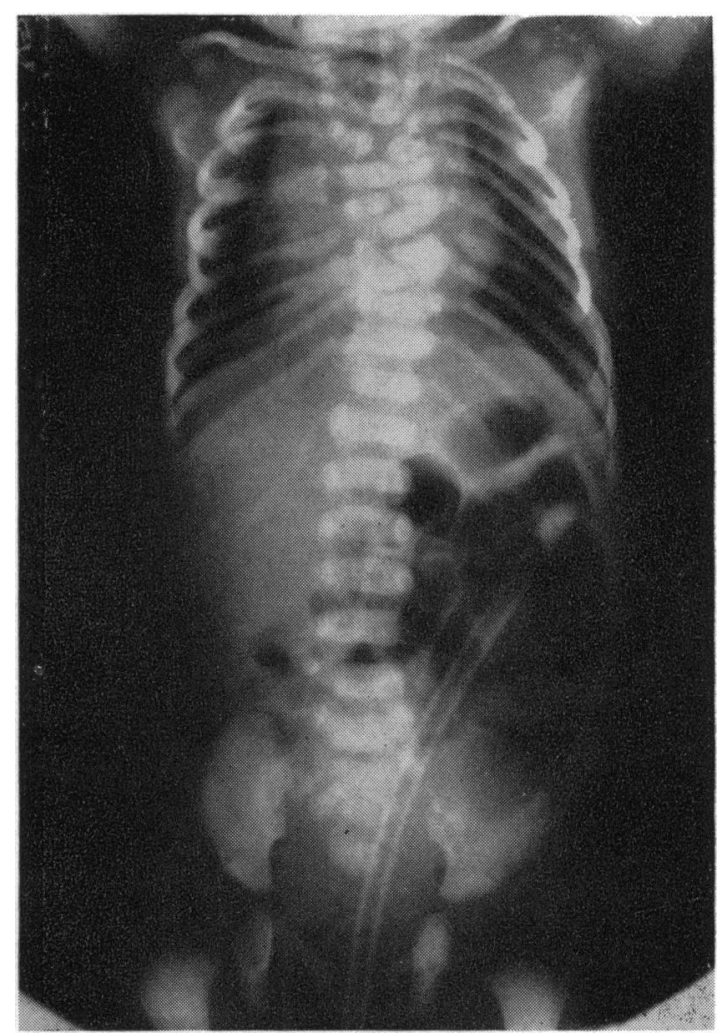

FIG. 5. Radiograph of a baby suffering from recto-vaginal fistula associated with bilateral hydronephrosis and hydroureters. Deformity of the thoracic vertebrae is also present.

ALIMENTARY TRACT LESIONS Oesophageal atresia is the commonest, though not in this series. It has been the practice to pass an oesophageal tube as a routine in most instances if the baby is seen before feeding has begun.

CONGENITAL LESIONS OF THE HEART These also were common in our series (five cases $(25 \%)$ in the high 
group and two ( $8 \%$ ) in the low group). Both cyanotic and acyanotic types occurred, including Fallot's tetralogy, septal defects, and transposition and patent ductus arteriosus. Two of the mongols had severe cardiac defects.

\section{TREATMENT}

In order to appreciate our results, an outline of the treatment adopted is necessary. In the case of low obstruction, i.e., below the pelvic floor, a perineal procedure was carried out; in most instances an opening was made at the anal site into the rectum, followed by gradual dilatation to normal size. Two children with anal stenosis did not come for treatment until they were 2 or 3 years old when the condition was first recognized.

In high obstruction a primary colostomy was carried out in the earlier cases, but later this procedure was restricted to infants with additional abnormalities which rendered an abdomino-perineal procedure too hazardous. In the last five years, a pull-through operation was performed as a onestage procedure a day or so after birth (Fig. 6). Also, infants with initial colostomies underwent reconstructive procedures at the age of a few months but in one the anus was restored when the child was $5 \frac{1}{2}$ years old. As a result of the restorative operation the rectum was straightened, and thus in most

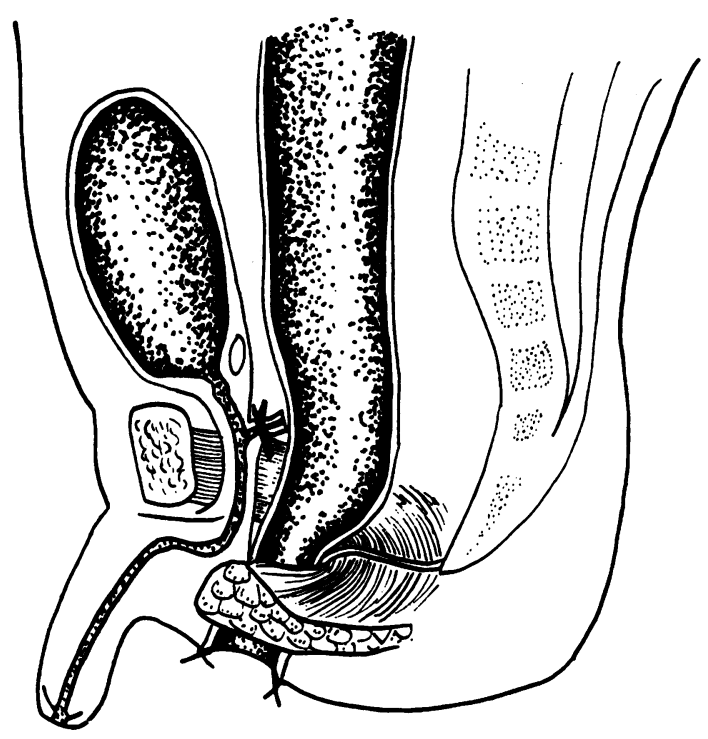

FIG. 6. Diagram showing final stage of reconstruction (pull-through) operation for recto-urethral fistula. The bowel adjacent to the fistula has been divided and drawn through the sling of the levator ani muscle and attached to the anal region. instances the terminal portion of the bowel was returned to that state conceived of in the teaching of Galen from which the anatomical name 'rectum' is derived. It is also of historical interest to learn that the pull-through procedure was devised as long ago as 1879 (MacLeod, 1880).

\section{RESULTS}

The results are shown in Table $I$ and we have classified them as 'good', 'fair', and 'poor'. This grouping is similar to that adopted by Gough and Partridge, who reviewed 323 cases treated at the Hospital for Sick Children, London (Gough, 1961). In the 'low' cases, normal bowel control without the use of regular laxatives is regarded as a 'good' result, and 'fair' if supervision was still required to treat constipation or stenosis. A 'poor' result denotes incontinence or severe bowel stasis. The high cases which were classed as 'good' became continent of faeces and urine, had spontaneous and regular bowel evacuation with only occasional soiling and had rectal sensation, whereas those which were continent except for loose stools were regarded as 'fair' and some of these may have required laxatives or suppositories. A 'poor' result was a child who lacked control with soiling.

Our patients have been followed for various intervals, the longest period being five years in the high group and 12 years in the low group. Some are too young to assess and these will be discussed later.

\section{DEATHS}

Mortality statistics must necessarily be explained because death may be due to the operation and its complications or to the associated anomalies. In our 20 high cases, there were three deaths attributable to the operation, or a mortality of $15 \%$. One baby died suddenly at home at the age of 3 months; the cause of death was not ascertained, even at necropsy. Another died when 6 months old. She was suffering from a cloacal defect and several anomalies. However, all the babies who succumbed after operation might well have died from the associated anomalies in due course. The mortality studies emphasized the well-known fact that anomalies are often multiple and may show up months after operation for the more obvious congenital deformity.

In the low group of 26 cases there was only one death, that of a mongol child who died at 6 months of age from congenital heart disease. It appears from these figures that the accompanying abnormalities in this group are more compatible with life and their possessors survive infancy. In Table $\mathrm{V}$ a comparison of previously recorded series of high ano-rectal 
TABLE V

\begin{tabular}{|c|c|c|c|c|c|c|}
\hline \multirow{2}{*}{$\begin{array}{l}\text { COMPARISO } \\
\text { Author }\end{array}$} & \multirow{2}{*}{$\begin{array}{l}\text { RECORD } \\
\text { No. of } \\
\text { Cases }\end{array}$} & \multirow{2}{*}{$\begin{array}{l}\text { Sex OF HIG } \\
\text { Distribution } \\
(\%)\end{array}$} & ANO-RECTAL & \multicolumn{2}{|c|}{ ORMITIES (IMPERFORATE RE } & \multirow{2}{*}{$\begin{array}{l}\text { ROUP) } \\
\text { Pull Through } \\
\text { Possible } \\
\text { (\%) }\end{array}$} \\
\hline & & & $\begin{array}{l}\text { Associated } \\
\text { Anomalies } \\
(\%)\end{array}$ & $\begin{array}{l}\text { Results }{ }^{1} \\
(\%)\end{array}$ & $\begin{array}{l}\text { Mortality } \\
(\%)\end{array}$ & \\
\hline $\begin{array}{l}\text { Stephens (1953b)) } \\
\text { Gough (1961) }\end{array}$ & $\begin{array}{r}30 \\
114\end{array}$ & $\begin{array}{l}854 \\
860\end{array}$ & $\begin{array}{l}57 \\
64\end{array}$ & $\begin{array}{l}\text { Good } 30 \\
\text { Fair } 40\end{array}$ & $\begin{array}{l}50 \\
36\end{array}$ & $\begin{array}{l}\text { Most cases } \\
60\end{array}$ \\
\hline This series & 20 & 880 & 75 & $\begin{array}{l}\text { Good } 25 \\
\text { Fair } \quad 37\end{array}$ & 20 & 65 \\
\hline
\end{tabular}

deformities is shown. The cases in each series are not strictly comparable because of lack of uniformity in the anatomical typing but illustrate that the overall mortality is about $25 \%$ and the associated anomalies are over $50 \%$.

\section{COMMENT}

'A properly functioning rectum is an unappreciated gift of greatest price' wrote Potts in 1959. The success of treatment depends on the integrity of the control of the bowel which consists of several components.

EXTERNAL SPHINCTER MUSCLES These are usually well developed in low anal lesions and remain intact and function normally; in high cases these muscles are rudimentary.

INTERNAL SPHINCTER This is represented by the circular coat of the terminal bowel; this mechanism is also well developed in low cases but not in high anomalies.

LEVATOR ANI SLING The levator ani sling of the pubo-rectalis muscle supports the rectum and helps the control of its lower part. Any defect of the sacro-coccygeal vertebrae results in poor development of this muscle and defective control and incontinence.

NERVE SUPPLY An intact nerve supply likewise may be deficient with deformity of the sacrum, and neurogenic bladder disorders may occur also.

Normally, the rectum is empty except just before defaecation, when the terminal colon contracts causing the rectum to fill and this distension produces the desire to defaecate. Rectal sensation is variable in anorectal anomalies, being present in the low type and mostly absent in the high. The parasympathetic nerve ganglia are usually present and normally distributed in the rectum of such cases but aganglionosis (Hirschsprung's disease) has not been found in the few cases which had been examined in this series. Thus, the behaviour of the colon above should be normal so that after a good 'action' of the bowel this portion should be emptied and remain so for several hours.

The success of treatment as regards continence depends on preserving as much of the bowel as possible and avoiding damage to the levator ani portion of the pelvic diaphragm. After pull-through operations the shelf of the pubo-rectalis sling can be felt per rectum in most cases, except where a sacral deficiency exists with consequent lack of myotome development.

The loss of rectal and anal sensation is serious and probably accounts for the children's delay in developing some voluntary control. It is difficult to train a child to contain his motions if he is unaware of their presence. Thus regular, patient training in adequate bowel emptying is necessary, and physiotherapy with electrical stimulation of the muscles of the pelvic floor does much to reproduce the action which the child, when old enough, can imitate.

A good mother is the best teacher, for the results are relatively better in those children who have good, devoted parental care. Likewise, if dilatation is carried out by intelligent parents a good passage is maintained, whereas others allow the anus to stenose. Supervision is most important in the first few weeks of life to maintain an adequate lumen and avoid trouble later. Nevertheless, constipation is prone to occur, especially in babies artificially fed. Washouts are necessary from time to time and rectovaginal fistulae are often troublesome and early transposition is necessary.

The institution of a colostomy is sometimes necessary but it is an extra burden for the mother in keeping the infant's skin in good condition and maintaining good colostomy actions. This by-pass procedure itself may be complicated by prolapse, intestinal obstruction, stenosis, and bleeding, and should be closed as early as practicable. In one instance the colostomy was made inadvertently in the ascending colon which was maldescended.

The tendency to carry out a pull-through operation as early as possible as a primary procedure is 


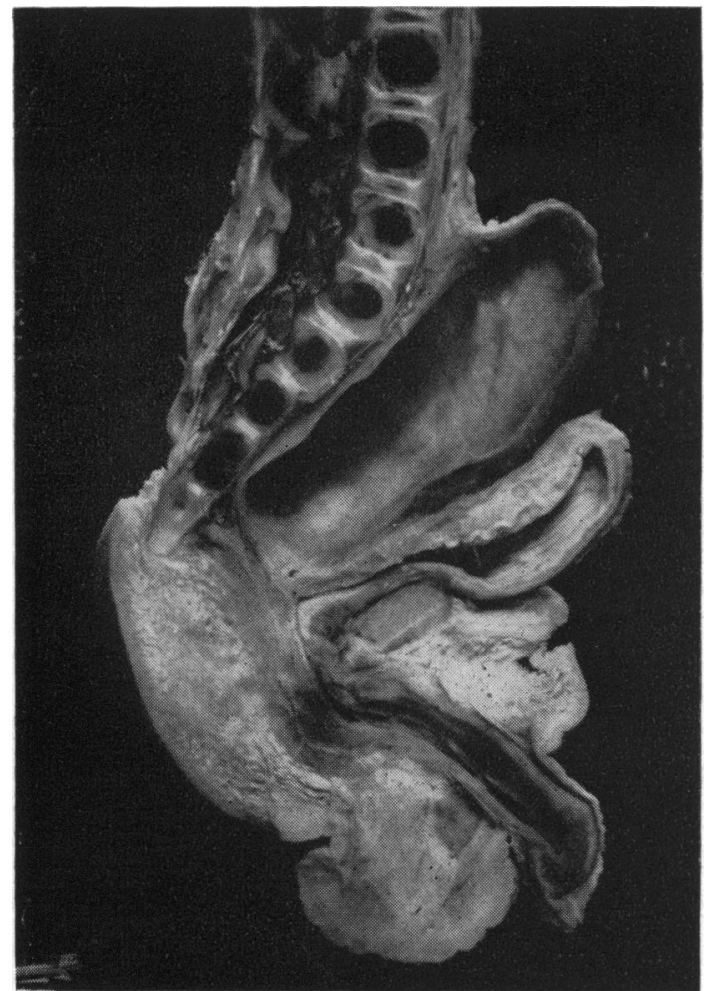

FIG. 7. Sagittal section through the pelvis of a specimen of ano-rectal agenesis.

often successful and safe and has much to commend it but the narrowness of the pelvic outlet in the neonate compresses the new rectum considerably and the levator ani muscles and also the delicate adjacent urethra may be damaged (Fig. 7). Perhaps a colostomy as a primary operation until the child is 6 months of age as a compromise will cause less damage and give better results. Certainly early separation of the urinary tract from the rectum in cases of fistula is essential to prevent urinary infection.

After reconstruction operations regular dilatation is needed, usually until the motions become firm and naturally keep the channel widely patent. Development of control is variable and it is best when the motions are firm whereas loose stools and flatus cannot be retained. Thickening the faeces by the use of Celevac may be helpful.

Parents should be 'warned that the control of the child's bowel actions may be delayed for several years but when the child goes to school he will appreciate the need for continence and cooperate to this end.

\section{REFERENCES}

Browne, D. (1955). Congenital deformities of the anus and the rectum. Arch. Dis. Childh., 30, 42-45.

Gough, M. H. (1961). Congenital abnormalities of the anus and rectum. Ibid., 36, 146-151.

Ladd, W. E., and Gross, R. E. (1941). Abdominal Surgery of Infancy and Childhood. Saunders, Philadelphia.

Macleod, N. (1880). Case of imperforate rectum, with a suggestion for a new method of treatment. Brit. med. J., 2, 657-658.

Potts, W. J. (1959). The Surgeon and the Child. Saunders, Philadelphia.

-, Riker, W. L., and DeBoer, A. (1954). Imperforate anus with recto-vesical, -urethral, -vaginal and -perineal fistula. $A n n$. Surg., 140, 381-395.

Rhoads, J. E., Pipes, R. L., and Randall, J. P. (1948). A simultaneous abdominal and perineal approach in operations for imperforate anus with atresia of the rectum and rectosigmoid. Ann. Surg. 127, $552-556$.

Stephens, F. D. (1953a). Congenital imperforate rectum, rectourethral, and recto-vaginal fistulae. Aust. N.Z. J. Surg., 22, 161-172.

- (1953b). Malformations of the anus. Ibid., 23, 9-24.

Swenson, O. (1958). Pediatric Surgery. Appleton-Century-Crofts. New York. 